\title{
Children as theological hermeneutic: Is there a new epistemological break emerging?
}

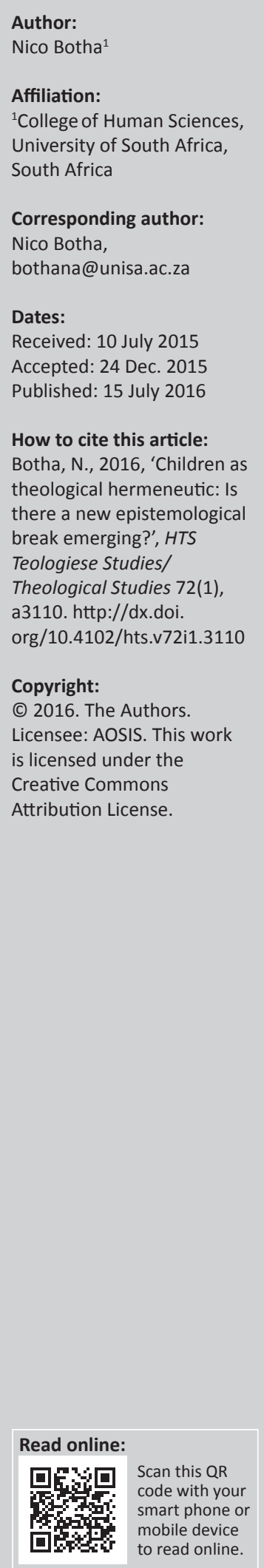

Children are the great omission in theology. The objective of the article is to show that there is a growing realisation of this reality. More than that, there are attempts afoot to salvage the situation by factoring children more and more into theological writing, not in an objectified manner, but as serious agents of theology and, in the case of this article, as agents of mission. A few examples to this effect are shown in the article. The main thrust of the study, however, is to raise the hypothetical question of whether children have not become an important and indispensable theological hermeneutic themselves. The serious question is raised of whether children if, taken seriously in church and theology are not forcing a new epistemological break or a new way of believing and of theologising on the world of mission. A somewhat tentative and hypothetical conclusion is arrived at, which suggests that indeed there is a new rupture occurring in terms of how we know what we know in church and theology.

\section{Introduction}

It is a gross understatement to speak of the neglect of children in theology in general and in missiology in particular. As a matter of fact, children are quite conspicuous in their absence in the theology we write, even when such theology is purportedly aimed at the entire human race or the whole church. This article is aimed not so much at increasing the volume of theology by factoring children into it or by making children part of our theological education; the main purpose of the article is to advance the following argument: children are forcing a new theological hermeneutic on us, which is beginning to make some people wonder whether we are not confronted with a new epistemological break. Previously, the poor in their struggles against oppressive economic systems, women in their battles against de-womanising patriarchy, and Mother Earth in her cry against the object-subject scheme of reality created by human beings for the plundering of nature have challenged theology and the church to develop new theories of knowledge. Are children challenging theology and the church to rethink, or should it rather be to re-enact or redo the manner in which we arrive at theological and ecclesiological knowledge?

To be clear, the question asked by the study on which this article reports was not whether adults care for or teach (or venerate) children (White 2011:5). Rather, the question is whether adults begin to understand that from the perspective of children there is an entirely different way of knowing the Kingdom or reign of God. The research question was consequently not about the sharpening and the improvement of Sunday school, the children's guild, the children's brigade, or the children's service once a quarter or more frequently. No, it goes deeper and has to do with what Nakah (cited in White 2011:148) hints at as the 'fruitful hermeneutical clue' and what Werner (2011:80) more pertinently calls 'a fundamental missiological priority principle'. In the continent of Africa, with its prevailing patriarchal cultural patterns, this is indeed quite a challenge, as the following example might illustrate. Much as the General Synod of a particular denomination resolved almost a decade ago that children could be served with the Holy Communion on condition that the proper pastoral process were followed with families who wished their children to partake of the table of the Lord, there is still fierce resistance in many a congregation. Once again, the research question presented here is not merely whether children are to join adults around the communion table, but whether the self-same adults are ready for a radical reorientation where children become the interpretive key for what happens in the ministry of the church.

Having stated the problem that passes the revue in the article somewhat, that is, having clarified the research question, we now proceed to indicate the manner in which the article is organised. First, a cursory look is taken at instances of reorientation in mission circles, with particular reference to Edinburgh 2010 and what has become known as the 4/14 Window or movement. Second, the notion of children as theological hermeneutic is introduced as more or less the main 
thrust or thesis of the article. Third, based on the centralisation of children in church and theology, the question is posed whether this constitutes a new epistemological break or just an extension to or a prolonging of the rupture that came about in theology with the emergence of modes of liberation theology and eco-theology. Fourth, does this have the potential to bring about a transformation of missiology as an academic discipline? Does this constitute an authentic postmodern missiology?

\section{A reorientation in mission circles}

One issue that has been emerging quite strongly in mission circles in the past decade or so is the negligence of children and the virtual absence of children from theology in general and missiology as a theological discipline in particular. This portion of the article is aimed at introducing two specific examples of a reorientation that might not only draw greater attention to children, but trigger an epistemological break.

\section{Edinburgh 2010}

The centenary of the famous Edinburgh 1910 mission conference was celebrated in Edinburgh, Scotland, from 2 to 6 June 2010. At the Edinburgh 2010 conference, the corrective on the negligence of children and their virtual absence from mission and missiology took on different forms. In theme or Commission 5 at Edinburgh 2010 on Forms of Missionary Engagement, for example, the issue of the mission of children was introduced. The formulation in itself hinted a significant shift from viewing children as objects of mission to seeing them as people in mission themselves (Kim \& Anderson 2011:156). There was enthusiasm about the issue of children in mission, but also concern about the care of children, their potential for exploitation, and a right recognition of childhood. The theological-missiological rationale for children in mission seemed to have been that Jesus placed a child among his disciples and also the key roles in mission played by several children in the Bible. In the report of the Listening Group at Edinburgh, there is talk of 'a new and refreshing concern' relating to 'the role of children as a new energy for twenty first century mission' (Kim \& Anderson 2011:315). In brief, therefore, Edinburgh 2010 hinted quite strongly, albeit it still in snippets and in a fragmentary fashion, that children were forcing a new mission hermeneutic upon us.

\section{The 4/14 Window}

Perhaps the strongest signal of a corrective emerging in mission circles, is the $4 / 14$ movement, where the gaze is on children ages from 4 to 14 as a major constituency for mission and the transformation of the world. Analogous to his 10/40 Window, Bush has constructed the 4/14 Window to draw attention to the importance of children of those particular ages as agents of mission and transformation in the world. If global summits are anything to go by, the agency and centrality of children in mission are taken so seriously that the 4/14 movement has had major world summits in New York (2009), Nairobi (2010), and Singapore (2011).

\section{Mission as prophecy}

The shift in emphasis from adults in mission to children in mission could potentially give new impetus to the understanding of mission as prophecy. The $4 / 14$ window is strongly informed by the prophecy from Joel, which reads as follows in the New International Version:

And afterward, I will pour out my Spirit on all people. Your sons and daughters will prophesy, your old men will dream dreams, your young men will see visions. (Joel 2:28)

There is an important dimension of prophecy that seems to be emerging in the 4/14 movement, which is the envisioning of a reality that is qualitatively different, a re-description (Brueggemann in his 2009 publication) of the world that is closer to what God sees. In his proposal for mission as prophecy and in elaborating on the content of the prophetic message, Kirk (2006:157-160) writes about the promise of new beginnings, lamenting the fact that this dimension of the prophetic message is quite often overlooked. He deals of course with the other dimensions of prophecy, namely the condemnation of idolatry and the warning about the consequences of idolatry, but then puts emphasis on the 'envisioning' dimension of prophecy. In simple terms, the new beginnings are the sending of a true liberator who will deliver people from their foolish ways and who will restore to them genuine wisdom. A most important aspect of the renewal will be the outpouring of the Spirit and the establishment of justice.

It is hugely interesting to note, for example, that Vanhoozer (2003:12) in the compilation on postmodern theology speaks of the 'recovery of two neglected forms of religious discourse - the prophetic and the mystical'. A genuinely postmodern missiology, and dare one say, a missiology informed by children as the mission hermeneutic, is a 'dream missiology' that capacitates people to see something other than what can be obtained in the present world (Vanhoozer 2003:12). It therefore comes as no surprise that for the auctor intellectualis of the Child Theology Forum (CTF), White claims that the prophecy from Isaiah 11 is central to child theology. In a very creative fashion, he integrates prophecy and mission in his piece entitled, 'A little child will lead them - Rediscovering children at the heart of mission'. The interpretive moment is not only the brilliant prophetic vision, but more importantly the centrality of children in the messianic kingdom.

\section{Children as theological hermeneutic}

Up to this point, we have given hints of a serious new construct, namely, children as theological hermeneutic. No serious attempt, however, has been made to elaborate on this idea. In proceeding now to a more extensive engagement with the notion, we review four issues in particular: margins as centre in mission, a call to conversion, mission in narrative mode, and mission in creative tension. 


\section{Margins as centre in mission}

In theology in general and in missiology in particular, a new hermeneutic has always arisen with the foregrounding of marginalised categories of people and issues. The theologicalmissiological notion of God's preferential option for the poor arose when attempts were made to look at political and socio-economic realities from the perspective of the poor. Greater understanding for the struggles of women against patriarchy emerged when the gaze changed from looking at reality from the perspective of a male-dominated and patriarchal world to an interpretation of the world from the perspective of women's experiences. In theology and in the church, the greater sensitivity for the devastation of the Earth by humans arose from the foregrounding of Mother Earth as equally in need of justice, as strongly suggested by the Confession of Accra (2004).

\section{The child foregrounded as a sign}

One of the foremost proponents of the 4/14 movement, Brewster (2011:183-185) draws attention to the issue that the Bible is a book full of signs in his interpretation of the theological significance of children. The fundamental theological rationale for the notion of children as hermeneutic is that Jesus offered a child as a sign of the kingdom of God (White 2011:55). However, the context in which this happens seems to be of paramount importance for a proper understanding of what Jesus was aiming at. The child is located centre stage by Jesus in a situation where his disciples were concerned about power, position, and greatness. In an appropriation to the South African theological and ecclesial context, one could say that the disciples' concern is about rewards for having participated in the struggle against apartheid in terms of coming as close as possible to the gravy pot. The only response from Jesus is to foreground a child as a sign of God's reign.

Different versions of the story are called into service to make the same point. Werner (2011:80) uses the story from Mark 9:36 for his contention that 'children are a fundamental missiological priority principle'. This is tautological language in a sense, aimed at making abundantly clear that in the encounter between Jesus and the children, 'the latter are drawn into the centre as an indispensable mark of his own ministry'. White (2011:55) uses Matthew 18 as the basis for his assertion that the child is a sign of the reign of God. In his interpretation of the story from Matthew 18, White (ibid: 55-56) cautions about vital aspects of the story that should not be overlooked. First, we know nothing of the character of the child, not even whether the child was male or female. The caution here seems to be against an overhasty assumption about the disposition of the child. White (date: page number) argues that any attempt at being very pious and politically correct in terms of attributing to the child particular qualities is misplaced. In a real sense, therefore, the child is the child and, simply for that reason, the child is identified by Jesus as a sign of the reign of God. And this is exactly what the second issue is about. To cite White (2011) himself:
... although the child is silent, the sign is not simply the child in the midst, standing in splendid isolation. The child has been placed by Jesus, and Jesus speaks about the child and explains how this little child is a sign of the Kingdom. (p. 55)

The third aspect raised by White is intriguingly important and points to the fact that Jesus is not bringing his own childhood into play here. In parallel to the tendency of speculating about the disposition of the child foregrounded by Jesus, the temptation to induce aspects of the childhood of Jesus in the interpretation of the text is virtually irresistible. White (2011:56) makes the point that Jesus never refers to his own childhood. He hurries, however, to show in his fourth point that the power of the sign lies exactly in the fact that the child is a sign of Jesus. The child represents Jesus in his nature, his way, his calling, and the cross. In Prevette's (in White 2011:64) interpretation the place metaphor serves as a 'theological clue' in that it points to something that the very disciples of Jesus have yet to grasp about the Kingdom. Let us now try to find out what it is that the disciples might have been missing.

\section{A call to conversion}

The context in which Jesus foregrounds or centralises a child is that of heavy debate amongst his disciples about issues of power. The metaphor of placing the child in the centre is sharply illustrated by the emblem of the Child Theology Movement (CTM) with twelve circles arranged in the form of a horseshoe with two figures, Jesus and a child, in the middle. At the very moment that adult males are concerned about their status and positions of power after the restoration of the political state of Israel, Jesus responds metaphorically. His response is not merely to induce a child in the metaphorical sense, but to place a physical, bodily child in their midst. Prevette (in White 2011:64) assists somewhat in speculating that the disciples might have assumed that they had '... certain truths and assurances in God'. He then poses the pertinent question:

Could it be that those we serve - the lowly, the broken, the abused, those that we see as recipients of our ministry - could they be pointers to something we have yet to understand in the Kingdom of God?

He then concludes that the placing of a child in the midst of the disciples points to humility and repentance.

In a word, the identification of a child as a sign of the Kingdom is a call to conversion. In a response to White's paper (2011:41-61) the UNISA missiologist James (in White 2011:69-73) indicates four dimensions of such conversion: humility, little things and little people, realignment, and repentance. For the moment, we would like to focus on the last two, namely, realignment and repentance. In the perspective of the child as a sign of the Kingdom, James understands the call to realignment as a call against triumphalism. In an insightful manner, she connects triumphalism to 'Christian power, ambition and the corporatization of Christian witness'. In my own interpretation the succumbing to the seduction of power and ambition that James refers to is indeed a contradiction to, and a subversion of, the sign of the child, who is a sign of the reign of God. In a 
profound manner, the placing of the child in the centre is a call to deep and ongoing repentance. In James' understanding (in White 2011:74) following White (2011:4-6) the very particular repentance that is required is to repent from the '... thinking and believing, that great, powerful, big and rich is equal to the Kingdom of God ... A review of our Kingdom epistemology and praxis is in order'.

\section{Mission in narrative mode}

We want to suggest that part of the reorientation or shift that is central to this article is a rediscovery of the Bible as a book of stories. Yet, even a statement like this would be in need of deconstruction by indicating quite clearly that the required shift is a shift that subverts the misconception that the Bible says very little about children.

In contradicting the misconception, White (2011) in his 'A little child will lead them' and Brewster (2011) in his workbook on 'Children and childhood in the Bible' have shown numerous names of children, references, and instances where children emerge as central to God's mission and as key to an interpretation of the reign of God.

All people all over the world, not only Africans, live in dream, story, and song. Beyond the trappings of the modernist trend to rationalise, to structure, to organise for purposes of containment, people live 'dreamt lives', 'storied lives', and 'sung lives'. However, to stay with the issue of story or narrative for a moment, we would like to suggest that in trying to show that the recourse to narrative is not a fad or a cop out, further research may be needed in the following distinct area: to bring the rediscovery of the Bible as a book of stories into critical discourse with interpretations of narrative by Hauerwas and Jones (1989), Healey (1996), Lucie-Smith (2007), Niebuhr (1967), Ricoeur (1985), Stroup (1984), and specifically in the field of missiology, by people like Van Engen, Thomas, and Gallagher (1999).

\section{Mission in creative tension}

Up to now a rather romantic picture might have emerged of the reorientation that the article has in mind. There is an even greater danger in foregrounding children in theology and church of presenting a rather sanitised and overly romantic portrayal of children. Speculation on the moral disposition of the child placed in the centre by Jesus feeds into an overtly romanticised image of the child. Bunge (2011:20) refers to this and similar images as 'simplistic views of children'. In elaborating somewhat on some of the simplistic views, she points to three. First, in reference to the United States, she refers to scholars who say that in a consumer culture, a 'market mentality' impacts on the attitudes towards children - this would of course be true in many countries in the world. Based on the market mentality, children are then identified as commodities, consumers, or economic burdens. Second, in conservative evangelical circles, children are seen to be 'sinful' and 'in need of discipline'. Third, main-line and more liberal churches see children as 'cute', 'innocent', or also 'insignificant'.
Bunge (2011: 20-29) goes on to propose that particular perspectives on children from the Bible should be held in creative tension. These perspectives include the notions that children are gifts of God and sources of joy, sinful creatures and moral agents, developing beings in need of instruction and guidance, fully human and made in the image of God, models of faith and sources of revelation, and in need of justice. Of particular importance for this article is the idea that children are sources of revelation. The issue of changing the gaze when it comes to children and to respect them as a new mission hermeneutic has to do with the challenge to accept the witness, prophecy, and revelation from children as representatives of Jesus (:26).

Towards the end of the 4/14 World Summit III in Singapore in September 2011, during the closing worship and celebration, some of the youth protested against their perceived marginalisation at a meeting that was supposed to be about them. On one level they objected to the fact that an outside praise and worship team was called into service instead of using the gifts that were available at the summit. On a more serious level, one of the youth leaders initially refused to accept an apology and confession from the main mover of the 4/14 movement, Luis Bush. Some adults at the summit, including a fellow South African, who tapped into his deepest cultural instincts, which still suggest that children should be seen and not heard, were infuriated. The point of the theological hermeneutic that is suggested in this article is that adults should, before anything else, learn to listen, learn to accept that children can sometimes be prophetic, and, more than that, that children can indeed be vehicles of revelation. The new hermeneutic suggests that adults should learn to see through their ears.

To prolong the anecdote on the 4/14 Global Summit somewhat, it needs to be pointed out that during the closing worship, quite an ugly side of some of the children on stage came to the fore. However, this is precisely the point Bunge (2011) is trying to make: that there is a need to see children and youths as dialectical beings.

The prospect of broadening the perspective on and commitment to children by holding divergent aspects in creative tension rather than in isolation (Bunge 2011:21), finds expression also in an interesting postcolonial perspective (cf. Hyde 2011:35-43). Hyde (2011:35-43) proposes that children should be viewed through a 'postcolonial' or 'decolonising' lens if postcolonial is understood in broad terms to extend beyond geographical colonisation. For him, the decolonising lens should assist in transcending the tokenistic inclusion of children and the conscious foregrounding of children in taking their voices and actions seriously. Such decolonising practice, according to Hyde, must hold in tension a number of seemingly opposite ideas.

\section{A new missiological epistemology}

Based on the discussion thus far, we suggest that the emergence of children worldwide as agents of mission necessitates a new epistemology. One of the building blocks 
of such an epistemology is the suggestion by Strachan (2011:283) of 'joining children in their world'. She implies quite strongly a shift in paradigm in hinting at a 'redress in favour of the children' (reference). The new missiological epistemology can only come to the fore if we start in the world of children and learn from their experiences. At Edinburgh 2010 in the theme on Mission and Postmodernities, one of the priorities was identified as the issue of experience being valued more than argument and its implications for Christian witness, in life, worship, and word (Kim \& Anderson 2011:141). Strachan (2011:283) goes on to line up children's stories from different parts of the world: Latin America, Asia, Europe, and Australia. She seems to suggest that unless this new manner of knowing is grounded in narrative, it will not offer anything new. The new missiological epistemology needs to be informed by the 'harsh realities of a child's world' and needs to 'create a synergy between theory and practice'.

However, the new missiological epistemology also needs to be theological. Important elements in this respect emerged in one of the drafts attempting at formulating a missiological basis for the 4/14 movement in Singapore at the Global Summit III. 'Mission', it is said, '... emanates from the heart of God who calls children to redemption and transformation in the words of Jesus Himself: "Let the children come unto me for theirs is the Kingdom of God"'. Further fundamental aspects identified are the incarnation-God taking the form of a child and being found in the house of God at age twelve where he speaks of things unseen and unheard of. In reference to the main thrust of the $4 / 14$ movement, namely the prophecy from Joel 2:28, the Spirit is said to be energising children for mission, calling them into service as agents of transformation.

\section{Is a new epistemological break emerging?}

Different angles have been introduced to answer the question of whether the reorientation towards children constitutes a new theological hermeneutic. We think we have succeeded to a certain extent in showing that the question is not merely whether more care or more attention should be devoted to children in theology and the church, but whether children in the perspective of the reign of God, present us with a new interpretive paradigm. The question that still needs to be answered is whether this new hermeneutic constitutes a new epistemological break. Such breaks have been experienced since the 1970s with the emergence of theological flows, which could in broad terms be identified as modes of liberation theology.

\section{Bachelard, Althussser, and Bosch}

Not so much the technical term, but the idea of an epistemological break originated with the philosopher Bachelard (1884-1962). As a social scientist, Bachelard constructed the notion of epistemological obstacles. His basic argument is that the progress of science is quite often blocked by mental patterns and that these obstacles need to be overcome. When such obstacles are indeed overcome or torn down, an epistemological rupture takes place. The French philosopher Althusser has taken Bachelard's thinking further in coining the notion of an epistemological break. For Althusser (n.d) an epistemological break occurs when a different set of central propositions are advanced than those previously held. Different questions are posed and a different theoretical framework is arrived at. For Althusser, knowledge is not discovered - for example, in terms of suddenly being able to connect a particular concept to the object it refers to. Knowledge is rather produced by way of what he perceives to be three generalities: 'raw material' or abstractions and facts; a particular 'problematic'; and a transformed theoretical entity or concrete knowledge. This new knowledge constitutes a break or a cut with previous ideological conceptions.

\section{Epistemological break in theological perspective}

For theology in general and missiology in particular, nobody has helped more than Bosch (1991) to interpret the idea of an epistemological break. The break in contextualisation, Bosch shows, is constituted by a cut (Althusser n.d.) between a theology from above, which is an elitist enterprise, and a theology from below. A theology from below, which is inductive in nature, breaks with the dominant epistemological approach of Western science, philosophy, and theology that are aimed at legitimising the status quo and protecting the interests of the West. Of course, in using this type of language, we remain wary of creating caricatures. The global reality has become much more complex and cannot simply be interpreted in terms of the old binaries between the West and the rest. A second issue as far as the epistemological break is concerned is to perceive the world not as a static object only to be explained, but as a reality to be changed. Thirdly, in a theology from below, the very first act is commitment. Therefore a theology from below is a 'with' theology. In concrete terms, and in the context of this article, a theology where purportedly children are the interpretive key cannot be a theology about or for children, but a theology 'with' children. In Africa the challenge of developing a theology with children might be greater than anywhere else. It is not for nothing that, in his reflection on the matter, Malherbe (2004) entitles his piece in the form of a question: 'Child theology in Africa?' The hesitancy derives from 'the lowly position children generally assume within African society' (Malherbe 2004:5). 'We may say', contends Malherbe, 'that in many parts of the continent children have not yet been discovered'. Malherbe (2011) contributes immensely to the discovery of children in Africa with his book entitled Saved by the lion? Stories of African children encountering outsiders. The diversity of stories from various African contexts presents theology with an important source. Even in South Africa, which is generally seen to be a more advanced and privileged country, the situation is far from ideal if a survey is to be taken seriously in which the country is exposed as 'child welfare negligent' (Malherbe 2004:6). Fifth, the epistemological break is constituted by the fact that a theology from below is a 'doing' theology - a theology informed by a hermeneutic of the deed. 


\section{Has an epistemological rupture been constituted?}

The question remains, does the new lens that is suggested in this article, the new handle, constitute an epistemological rupture? Initially, we were tempted to come to the following conclusion: the most we can say is that this new hermeneutic forced upon us by children is an extension or a prolonging of the same break in theoretical framework that emerged in theological flows around the world in the late 1960s and early 1970s. We have had a rethink on the basis of a set of very simple but pertinent questions: Is the poor, destitute child factored into Latin American liberation theology? Is feminist or womanist theology informed by the context of the lowly, marginalised girl child? Is Black theology based on the experiences of the black, hungry, sick, illiterate township child? Are these mere rhetorical questions - academic questions for that matter? No, these are life and death questions and the categorical answer to them is, no!

An important insight from the reflection on paradigm shifts (Kuhn 1970) is that from time to time there are anomalies operating in science that cannot be explained by the universally accepted paradigm, if paradigm is understood not only as referring to the current theory, but to the entire worldview in which it exists. With reference to children in relation to theology, church, and society, there are numerous anomalies operating. In theology, the need for developing good Sunday school material will be acknowledged, yet such material might be produced without any manner of input from children. In the church, children will forever be present in the Sunday school, the children's guild, the children's brigade; they will watch on with starry eyes when adults take their place at the communion table, but hardly ever will the 'lens of the child' be used 'in order to provide new insights into central themes of the Christian faith, e.g. how would we redefine the doctrine of the church if we took children seriously?' (Nakah in White 2011:149).

In South African society in particular and Africa in general the challenge posed by children as a new lens for interpreting the social, cultural, political, and economic realities is the more serious. In context, therefore, the South African/African child who is foregrounded is still very much the one who lifts a clenched fist; the AIDS orphan; the child soldier; the illiterate; the molested; the abused; the hungry; the child whose parents still face the triple challenge of being unequal, uneducated, and unemployed. These are the ones whom Jesus places in the centre to reveal to us the meaning of church and of the Kingdom of God. To see this is to understand that a whole new paradigm, a rupture, is emerging, for which theology and the church must account.

\section{Conclusion: Children making knowledge: White and Willmer}

One South African expert in the area of child theology who has been approached to assist in understanding the feedback from a reviewer of this article suggests that the contribution should not be projected as novel and that greater acknowledgement of the child theology movement relating to the epistemology emerging in the article should be recorded. In brief, therefore, any notion of a new epistemology without due recognition of the contributions of the likes of White and Willmer (2014:111-120) would not make sense, much as neither of the two uses the term epistemology. Malherbe (2015) briefly interviewed as a home-grown specialist on child theology contends that the mere use of terms like epistemology throws up a problem in that it is too modernist and anyway difficult for children to grasp. In staying with the concept, however, some clarification could be offered by saying that an epistemology in its simplest terms is about how we know what we know, or it is about how we make knowledge. To suggest children as theological hermeneutic is a way of saying that through children and their real-life world in general, and their participation in mission as reputable agents in particular, we gain as well as create new knowledge.

In their chapter titled 'Theology, mission and child under the shadow of the cross and in light of the Resurrection', White and Willmer (2014:113) contend, without explicitly saying so, that this new epistemology seems 'to be jarred by the rugged encounters with real children and their difficult contexts'. In a rather deep reflection, they bring the reality of children into discourse with the cross of Jesus Christ. In a real sense the new way of knowing that they suggest is, if it is not too much of a caricature, not knowing. It is a matter of being 'disarmed and forced to stop in our tracks' (p. 114). They suggest a type of knowing characterised by 'an absence of God, of health, of life, of goodness'. In relation to the cross of Jesus Christ it is all about: 'My God, my God, why hast thou forsaken this child/me/your beloved Son'.

In a reading in front of the text, which is the reading strategy for identifying key words or images, of the chapter under discussion here, one is struck by the appearance of the darkness metaphor in the text. The metaphor is called into service in relation to the cross and the context of a specific category of children. This new way of knowing what we know through the lens of children is indeed unsettling and uncomfortable. Concrete examples with reference to the suffering of a Botswana girl, a South African street boy, or post-Communist children in Romania, in the understanding of the two authors, White and Willmer, 'are brought into the very centre of our beings'.

Moreover, since this article contributes to a festschrift in honour of Duncan, it needs to be mentioned perhaps that feeding into liberating, healing, and empowering epistemologies has never been strange to him. Duncan (2005:51-75) has contributed specifically to a new mission historiography or, one could say, a new way of making knowledge in the theological discipline of missiology. For him, the history of the oppressed is a corrective to that of 'Conquerors and Servants of God'. This new historiography 
with reference to Christianity in Africa, and particularly South Africa, gives a serious account of the black experience and examines history from the 'underside of the poor and marginalized', which in Duncan's understanding is 'the ongoing experience of ordinary people' (p. 72).

\section{Acknowledgements Competing interests}

The author declares that he has no financial or personal relationships which may have inappropriately influenced him in writing this article.

\section{References}

Althusser, L. n.d., The epistemological break, viewed 6 July 2015 from http://en. Wiki./ Louis Althusser The epistemological break

Bachelard, G. Epistemological breaks: The discontinuity of scientific progress, viewed 6July 2015 from https://en.wikipedia.org/wiki/GastonBachelard\#Epistemological_ breaks_the_discontinuity of scientific-progress

Bosch, D.J., 1991, Transforming mission. Paradigm shifts in theology of mission, Orbis Books, Maryknoll.

Brewster, D., 2011, Children and childhood in the Bible: A workbook, Compassion International, New York.

Brueggemann, W., 2009, Redescribing reality. What we do when we read the Bible SCM Press, London.

Bunge, M.J., 2011, 'Biblical understanding of children and childhood: resources for the church and mission today', in S. Arles, D. Brewster, C.B. Kok, R. Tan \& K.J. White (eds.), Now and next. A compendium of papers presented at the Now and Next Theological Conference on Children, pp. 15-34, C.O.S Printers, Singapore.

Duncan, G., 2005, 'Historiography and ideology in the (mission) history of Christianity in Africa', Studia Historiae Ecclesiasticae XXXI(1), 51-72.

Hauerwas, S. \& Jones, L.G., 1989, Why narrative?: Readings in narrative theology, WB Eerdmans, Grand Rapids, MI.

Healey, J., 1996, Towards an African narrative theology, Paulines Publications Africa, Nairobi.

Hyde, B., 2011, 'Steering a path along a treacherous course: Children's voices, colonization and religious education', Journal of Religious Education 59(2), 35-43.

James, G., 2011, 'Response to white's children signs of the Kingdom', in S. Arles, D. Brewster, C.B. Kok, R. Tan \& K.J. White (eds.) Now and next. A compendium of papers presented at the Now and Next Theological Conference on Children, pp. 69-73, C.O.S Printers, Singapore.

Kim, K. \& Anderson, A (eds.), 2011, Mission today and tomorrow, Regnum, Oxford.
Kirk, A.J., 2006, Mission under scrutiny: Confronting contemporary challenges, 1st edn., Fortress Press Minneapolis, MN.

Kuhn, T., 1970, The structure of scientific revolutions, University of Chicago Press, Chicago, IL.

Lucie-Smith, A., 2007, Narrative theology and moral theology: The infinite horizon, Ashgate, England.

Malherbe, J., 2004, 'Child theology in Africa?', Paper presented at the Hear the cry conference, held in Nairobi, Kenya from 17-21 May.

Malherbe, J., 2011, Saved by the lion? Stories of African children encountering outsiders', Roodepoort About Children.

Malherbe, J., 2015, Interview conducted on 19 November 2015 in his capacity as an expert on Child Theology. Malherbe is currently the principal of the South African Theological Seminary (SATS) based in Johannesburg.

Nakah, V. \& Malherbe, J., 2011, 'Child theology - A challenge to seminaries', in S. Arles, D. Brewster, C.B. Kok, R. Tan \& K.J. White (eds.), Now and next. A compendium of papers presented at the Now and Next Theological Conference on Children, pp. 135-149, C.O.S Printers, Singapore.

Niebuhr, R., 1967, Christian history and interpretation: Studies presented to John Knox, University Press, Cambridge.

Prevette, B., 2011, 'Reading the Signs - Kingdom and Child Theology for Practitioners', in S. Arles, D. Brewster, C.B. Kok, R. Tan \& K.J, White (eds.), Now and next. A compendium of papers presented at the Now and Next Theological Conference on Children, pp. 62-67, C.O.S Printers, Singapore.

Ricoeur, P., 1985, Time and narrative, University of Chicago Press, Chicago.

Strachan, W., 2011, 'Welcoming children - Reinstating children in our theological reflections in mission', in K. Kim \& A. Anderson (eds.), Mission today and tomorrow, pp. 140-148, 280-285, Regnum, Oxford.

Stroup, G.W., 1981/1984, The promise of narrative theology: Recovering the gospel in the church, John Knox Press, Atlanta.

The Confession of Accra: Covenanting for Justice in the Economy and the Earth, The Accra Confession was adopted by the delegates of the 24th General Council of the World Alliance of Reformed Churches in Accra, Ghana (2004), a predecessor body of the World Communion of Reformed Churches.

Van Engen, C., Thomas, N. \& Gallagher R. (eds.), 1999, Footprints of God: A narrative theology of mission, MARC, Monrovia, CA.

Vanhoozer, K.J. (ed.), 2003, The Cambridge companion to postmodern theology, Cambridge University Press, Cambridge.

Werner, D., 2011, 'The church and the child - ecumenical heritage and perspectives for the future', in S. Arles, D. Brewster, C.B. Kok, R. Tan \& K.J. White (eds.), Now and next. A compendium of papers presented at the Now and Next Theological Conference on Children, pp. 107-121, C.O.S Printers, Singapore.

White, K.J., 2011, 'Children as signs of the kingdom of god - A challenge to us all', in S. Arles, D. Brewster, C.B. Kok, R. Tan \& K.J. White (eds.) Now and next. A compendium of papers presented at the Now and Next Theological Conference on Children pp. 41-61, C.O.S Printers, Singapore.

White, K.J. \& Willmer, H., 2014, 'Theology, mission and child under the shadow of the cross and in the light of the resurrection', in B. Prevette, K.J. White, C.R. Velleso Ewell \& D.J. Konz (eds.), Theology, mission and child. Global perspectives, pp. 111-120, Regnum Books International, Great Britain. 